\author{
Dariusz Szczukowski (D) https://orcid.org/0000-0002-3407-9584 \\ Uniwersytet Gdański \\ dariusz.szczukowski@ug.edu.pl
}

\title{
Wolałbym tak. Obietnice szkolnej polonistyki ${ }^{1}$
}

\section{Would Rather It Were So. Promises of Polish Studies in Schools}

\begin{abstract}
This article is an attempt at rethinking school Polish studies in the perspective of post-critical pedagogy, in which the school is understood as a common good that serves the purpose of renewing the ties with the world. In this context, Polish studies become a space for building a democratic community of reading subjects. Therefore, they cannot be reduced to the production of particular ideological attitudes, nor can they be enclosed in an engineered school machinery designed to effectively fulfil the core curriculum.
\end{abstract}

Keywords: Polish studies, post-critical pedagogy, literary education

Streszczenie: Artykuł jest próbą przemyślenia polonistyki szkolnej w perspektywie pedagogiki postkrytycznej, w której to szkoła jest rozumiana jako dobro wspólne, służące do odnawiania więzi ze światem. W tym kontekście edukacja polonistyczna staje się przestrzenią budowania demokratycznej wspólnoty czytających podmiotów. Dlatego też nie można redukować jej do produkowania określonych postaw ideologicznych, a także zamknąć w zaprojektowanej maszynerii szkolnej służącej do efektywnego wypełniania podstawy programowej.

Słowa kluczowe: edukacja polonistyczna, pedagogika postkrytyczna, kształcenie literackie

\section{Szkoła i dobro wspólne}

W refleksji o edukacji dominuje przede wszystkim myślenie o szkole jako instytucji, podlegającej różnym mechanizmom społecznym i kulturowym, co oczywiście nie może dziwić. Inaczej na nią będziemy patrzeć z perspektywy konserwatywnej - szkoła w tym wypadku będzie gwarantem ustalonego porządku

1 Tekst powstał w ramach realizacji projektu „Ponowoczesna dydaktyka polonistyczna. Teoria i praktyka”. Nr umowy 0183/NPRH4/H2a/83/2016. 
społecznego, inaczej z pozycji liberała, dla którego szkoła miałaby być poszerzeniem sfery wolności, kształceniem indywidualnych wrażliwości, a jeszcze inaczej z perspektywy radykalnej, w której szkoła przejęłaby na siebie rolę awangardy dla zmiany społecznej. Te oczywiście rażąco uproszczone przykłady pokazują, że szkoła będzie zawsze miejscem politycznego agonu, a każda jej zmiana wiąże się z uaktywnieniem edukacyjnego dyskursu w przestrzeni publicznej. W wypadku ostatniej reformy ten dyskurs został głównie zdominowany przez spór między obrońcami gimnazjów a zwolennikami powrotu do ośmioklasowej szkoły podstawowej. Spór oczywiście ważny, w gruncie rzeczy dotyczy jednak sprawy technicznej, nie podejmuje podstawowego namysłu nad sensem szkoły.

Dlatego warto powrócić do zasadniczego pytania o sens szkoły, o którym przypomina pedagogika postkrytyczna ${ }^{2}$. Pedagodzy tego nurtu zauważają konieczność przekroczenia teorii krytycznej, odsłaniającej coraz to bardziej wyrafinowane mechanizmy władzy i przemocy wpisane w funkcjonowanie szkoły. Próbują przemyśleć istotę szkoły, zastanowić się nad obietnicą wpisaną w jej istnienie. Jan Masschelein i Maarten Simons - patroni nurtu postkrytycznego w pedagogice - w książce In Defence of the School. A Public Issue przypominają, że szkoła z greckiego $\sigma \chi 0 \lambda \eta \dot{~ o z n a c z a ~ c z a s ~ w o l n y . ~ P e d a g o d z y ~ d o p r e c y z o w u j a ̨, ~}$ że chodzi tu przede wszystkim o źródłowe greckie znaczenie tego sformułowania oznaczającego tyle, co czas wolny od pozycji społecznej uwikłanej w różne porząaki dominacji, w którym to - mówiąc innym językiem - cała nastawiona na zysk sfera produkcji oraz domena politycznych rozgrywek zostaje zniesiona. Czas szkoły jest zatem czasem nieproduktywnym, niewydajnym - nie da się go przypisać do codziennej aktywności. Szkoła dla Masscheleina i Simonsa byłaby przestrzenią budowania wspólnoty na „przekształceniu wiedzy i celów w dobro wspólne”3. To myślenie o szkole jako dobru wspólnym wpisuje się w logikę troski i odpowiedzialności, będącej rekonfiguracją naszej pozycji w świecie. W edukacji chodzi bowiem o samą edukację, której nie można instrumentalizować i „upolitycznić” w sensie tworzenia "dobrego obywatela” czy realizacji określonego celu w ramach znanej trajektorii przejścia ze stanu ignorancji do przestrzeni wiedzy czy bycia zdolnym do ciagłej produktywności i konsumpcji ${ }^{4}$. Szkoła nie jest zatem miejscem do wytwarzania produktów podległych prawom konsumpcji, jej podstawowymi wyznacznikami są bezinteresowne skupienie się na rzeczach, uważność wobec świata.

Joris Vlieghe i Piotr Zamojski, wnikliwi czytelnicy książki belgijskich pedagogów, w pracy Towards an Ontology of Teaching. Thing-centred Pedagogy, Affirmation and Love for the World wskazują, że podstawową dyspozycją nauczycielską

2 Zob. chociażby N. Hodgson, J. Vlieghe, P. Zamojski, Manifesto for a Post-Critical Pedago$g y$, https://punctumbooks.com/titles/manifesto-for-apost-critical-pedagogy, dostęp: 2.10.2019.

3 J. Masschelein, M. Simson, In Defence of the School. A Public Issue, tłum. J. McMartin, Leuven 2013, s. 10.

4 Zob. N. Hodgson, J. Vlieghe, P. Zamojski, dz. cyt. 
jest „moment nauczania, w którym ujawnia się nasza miłość do świata”. Termin „miłość do świata” (love for world) nie ma nic wspólnego z sentymentalną, naiwnie brzmiącą formułą. Pedagodzy pojmują go za Hannah Arendt jako próbę tworzenia relacji ze światem opartej na myśleniu i skupieniu. Nauczanie nie jest bowiem niczym innym jak zwracaniem uwagi na to, co stanowi dla nas wartość, czym chcemy podzielić się z uczniami. Dlatego szkoła pojmowana jest przez pedagogów w kategoriach daru, niemieszczącego się w logice ekonomii i zysku, wymykającego się wszelkim możliwym parametryzacjom i wymiernej ocenie 6 . Vlieghe i Zamojski swój projekt szkoły radykalnie przeciwstawiają dominacji neoliberalnego porządku, chcącego zredukować edukację do ciąłego samokształcenia, w którym to musimy się uczyć, aby stać się „produktywnymi, elastycznymi i niezawodnymi częściami społeczeństwa opętanego ideą ekonomicznej produktywności”’. Podobnie, chociaż z innej pozycji, diagnozuje Bernard Stiegler. Dominacja nastawionej na zysk ekonomii osłabiła - jak mówi filozof - międzypokoleniowe przekazywanie zaleceń, „które zawsze przygotowują do wejścia w obywatelskość i w uprzejme życie z innymi (...), stworzyła pozbawione więzi dryfujące jednostki”'. Dla francuskiego myśliciela marketing jest jednym z podstawowych elementów kontroli pragnienia i uwagi widocznej w przestrzeni teleinformatycznej wszechwładzy, prowadzącej przede wszystkim do reorganizacji rozumienia wiedzy, co niestety widać także w polityce edukacyjnej Unii Europejskiej. Według filozofa Komisja Europejska „zupełnie zrezygnowała z uczynienia z Europy oczytanego społeczeństwa i skupiła się wyłącznie na utworzeniu rynku europejskiego i poddaniu życia akademickiego jedynie przyczynowości sprawczej, a więc efektywnej, nie rozróżniając pomiędzy wiedzą a informacją" rą oczytania - tej niezbywalnej wartości - która nie została nawet pomyślana przez machinę polityczno-administracyjną. Metaforę oczytania, przynależącą do tradycyjnego repertuaru antykwarycznej filologii i kantowskiej idei oświecenia, utożsamia z produkcją wiedzy, dającą nadzieję na poszerzenie społeczności ludzi czytających, którzy nie poddają się łatwo dyktatowi władzy i jednocześnie potrafią mówić w swoim własnym imieniu. Stiegler nawołuje przede

5 J. Vlieghe, P. Zamojski, Towards an Ontology of Teaching Thing-centred Pedagogy. Affirmation and Love for the World, Cham 2019, s. 25.

6 Neil Postman wskazuje, iż hegemonia oceniania prowadzi do przeświadczenia, iż całą naszą egzystencję można w łatwy sposób zmierzyć i ustanowić jej wartość: „Stawianie stopni dostarcza "obiektywnej« miary dokonań człowieka, a zarazem prowadzi do niezachwianego złudzenia, że można dokładnie obliczyć czyjąś wartość". N. Postman, Technopol. Triumf techniki nad kultura, tłum. A. Tanalska-Dulęba, Warszawa 2004, s. 169.

7 J. Vlieghe, P. Zamojski, Towards an Ontology of Teaching Thing-centred Pedagogy..., dz. cyt., s. 26.

8 B. Stiegler, Wstrzasy. Gtupota i wiedza w XXI wieku, tłum. M. Krzykawski, Warszawa 2017, s. 535.

9 Tamże, s. 533-534. O myśleniu szkoły w kategoriach ekonomicznych zob. E. Potulicka, J. Rutkowiak, Neoliberalne uwiktania edukacji, Kraków 2010. 
wszystkim do kształcenia skupienia uwagi. Powinno ono organizować praktykę edukacyjną od wczesnoszkolnej aż po akademicką. Uważność i skupienie wyznaczają budowanie wiedzy niepodlegającej natłokowi informacji i łatwości prokurowania sądów pozbawionych refleksji.

Dla Vlieghe’a i Zamojskiego szkoła jest próbą odnawiania więzi, która wydarza się ze względu na specyficzną pozycję szkoły. Za Arendt wskazują, że szkoła pozostaje tworem niemieszczącym się w przestrzeni oikos (prywatnych przyjemności), ale też i nie przynależy do polis (powinności obywatelskich) ${ }^{10}$. Nie znaczy to, że szkoła jest odseparowana od sfery publicznej. W szkole bowiem nauczyciel upublicznia to, co jest godne namysłu, z czym warto się podzielić z uczniami: „szkoła i nauczyciel kładą coś na stole - coś, co staje się przez to "dobrem publicznym" i konsekwentnie sytuuje każdego w równej początkowej pozycji i daje każdemu szansę rozpoczynania od początku" ${ }^{\prime 1}$. Szkoła zatem ma charakter performatywny, wytwarza podmiotowości gotowe zaczynać wszystko od nowa, tworzące wspólnotę skupioną na ćwiczeniu i studiowaniu rzeczy, w której to nie ma podziału na nauczycieli depozytariuszy wiedzy i uczniów ignorantów.

Metafora czasu wolnego dobrze opisuje również doświadczenie literatury. Czas lektury (by przywołać tutaj tytuł książki Krystyny Koziołek) jest czasem wolnym ${ }^{12} \mathrm{w}$ tym sensie, że zawiesza nie tylko wszelkie powinności proceduralne, gdyż nie można jej sprowadzić do mechanicznego podporządkowywania jej odgórnie narzuconym celom i standardom, ale także „osadzenie” w rzeczywistości społecznej, staje się rekonfiguracją naszego doświadczania świata i siebie. Lektura stanowi sieć komunikacyjną, w której to „ja” nie jest samotnym, odseparowanym od świata podmiotem, lecz istnieje relacyjnie. Szkoła zatem musi zostać tak zaprojektowana, by stała się miejscem wspólnego czytania, komentarza, miejscem na czytelniczy performans, co wymaga oczywiście odpowiednio skonstruowanego procesu edukacyjnego ${ }^{13}$. Koziołek pisze:

Racja, w imię której skłaniamy siebie nawzajem do czytania wielkiej literatury, musi być jasna i nieodparta, i taką chcę usłyszeć w bliskiej mi szkolnej polonistyce. Szkoła czytająca mówi nauczycielom i uczniom: tu nie czytamy wyłącznie dla siebie, tu czytamy dla lepszego świata ${ }^{14}$.

Szkolna lektura dla „lepszego świata” zakłada praktykowanie takiej wspólnoty, która nie będzie wytwarzała różnych form autorytarnej władzy

10 Zob. H. Arendt, Kryzys edukacji [w:] tejże, Między czasem minionym a przysztym. Osiem ćwiczeń z myśli politycznej, tłum. M. Godyń, W. Madej, Warszawa 1994.

11 J. Masschelein, M. Simson, dz. cyt., s. 62.

12 K. Koziołek, Czas lektury, Katowice 2017.

13 Zob. A. Janus-Sitarz, W poszukiwaniu czytelnika. Diagnozy, inspiracje, rekomendacje, Kraków 2016.

14 K. Koziołek, dz. cyt., s. 254. 
i bezrefleksyjnie odtwarzała kulturowe pewniki. Szkoła czytająca w swym sercu umieszcza literaturę, a ta - jak powiada Jacques Derrida:

z zasady pozwala powiedzieć wszystko, wyłamać się spod reguł, przemieścić je (...). Zachodnia instytucja literatury, w swej stosunkowo nowoczesnej formie, powiązana jest z prawną gwarancją powiedzenia wszystkiego i bez wątpienia także z wyłanianiem się nowoczesnej idei demokracji ${ }^{15}$.

Zestawienie literatury z demokracją, która - jak wiemy z książki Derridy Inny kurs - ,jest obietnicą ${ }^{16}$, wskazuje na szkołę jako instytucję umożliwiającą otwarcie na polifoniczny charakter kultury i wielość języków opisujących naszą egzystencję. W koncepcję czytającej szkoły wpisana jest zatem obietnica wolnego czasu, odnawiania relacji z sobą i ze światem.

Nawet jeśli szkoła i lektura dają obietnicę czasu wolnego, to jednak obie mimo pragnienia bezwarunkowości - wpisane są w określoną sytuację kulturową i polityczną.

\section{Po reformie}

Jesteśmy już po reformie - używam tutaj przyimka „po” nie dlatego, by wskazać, że obecna reforma już się zakończyła i zgodnie z pobożnymi życzeniami jej rzeczników cel został osiągnięty: nasze szkolnictwo ma się świetnie, a narzekanie możemy zostawić wiecznym malkontentom. Właściwie jesteśmy w jej trakcie - nie wiemy chociażby, jak będzie wyglądał nowy egzamin maturalny z języka polskiego w roku szkolnym 2022/2023, jako dydaktycy uniwersyteccy zmagamy się także ze zmianami związanymi z kształceniem przyszłych nauczycieli. Używam tego przyimka „po”, gdyż interesujący jest „efekt” reformy, jaki ona przynosi dla polonistyki szkolnej. Zresztą sami twórcy reformy wyraźnie zaznaczają, choćby w komentarzu do nowej podstawy programowej do języka polskiego, że mamy do czynienia ze zmianą paradygmatu w polonistyce szkolnej. Wioletta Kozak nie zawaha się oznajmić: „Nowa podstawa w zasadniczy sposób zmienia paradygmat myślenia o języku polskim jako najważniejszym przedmiocie w szkolnej edukacji”'17. Przyznajmy, że to odważne twierdze-

15 J. Derrida, Ta dziwna instytucja zwana literatura. Z Jacquesem Derrida rozmawia Derek Attridge, tłum. M.P. Markowski, „Literatura na Świecie” 1998, nr 11-12, s. 181-182.

16 Tenże, Inny kurs, tłum. T. Załuski, Warszawa 2017.

17 W. Kozak, Komentarz do podstawy programowej przedmiotu jezyk polski na II etapie edukacyjnym [w:] Podstawa programowa ksztatcenia ogólnego z komentarzem. Szkota podstawowa. Jezyk polski, Warszawa 2017, s. 24. Dodajmy: podstawa programowa jest dokumentem obciążonym instytucjonalną władzą szkoły pojętej w ramach urządzenia, które jak twierdzi Giorgio Agamben - „ma zdolność pochwycenia, ukierunkowania, określenia, 
nie. Jeszcze przed ostatnią reformą Marek Pieniążek wskazywał na konieczność przekonfigurowania przedmiotu język polski, dostrzegając jednocześnie uporczywe zamknięcie szkoły przed ponowoczesnością i performatywnością ${ }^{18}$. Badacz zaznaczał:

Poetyka dyskursu edukacyjnego byłaby nienormatywną, wydobywaną z artystycznych i naukowych świadectw technik bycia (w ujęciu Michela de Certeau) wiedzą o transgresywnej inwencji i energii potrzebnej do uaktywnienia projektującego siebie aktora społecznego (Bruno Latour). Z powodu geolokalizacji naszego projektu należy dodać: projektującego siebie po polsku, czyli z uwzględnieniem wiedzy o historycznych aspektach środkowoeuropejskiego doświadczenia determinującego język i dziedziczoną mentalność, rozgałęziającą się w rozmaite ścieżki jej relatywizacji, a to w toku reinterpretacji scenariuszy kulturowych czy np. rozszczelnienia esencjonalnych tożsamości w cyklu globalnych otwarć interakcji kulturowych ${ }^{19}$.

Postawienie w centrum języka polskiego - tak rozumiem Pieniążka - nie jest formą oporu wobec globalnego świata w imię wzmacniania narodowej tożsamości, lecz raczej ma na celu wytwarzanie nowych scenariuszy biograficznych i społecznych, sytuujących się na przecięciu różnych praktyk tożsamościowych i kulturowych. Zamysł architektów reformy jest jednak inny. Przypomnijmy słowa Jarosława Kaczyńskiego:

Krótko mówiąc - nowa, aktywna, nastawiona na obronę polskiej godności i polskiego interesu narodowego polityka historyczna. Ona wiąże się ściśle z polityką oświatową, bo kształtowanie tożsamości młodych Polaków (...) musi opierać się nie o wstyd - jak to dzisiaj się robi - tylko o godność i dumę ${ }^{20}$.

przechwycenia, modelowania, kontrolowania i zabezpieczania gestów, sposobów postępowania, opinii i wypowiedzi istot żywych" (G. Agamben, Czym jest urządzenie?, tłum. J. Marmurek [w:] Agamben. Przewodnik Krytyki Politycznej, Warszawa 2010, s. 92). Mówiąc innym językiem, podstawa programowa wytwarza ciąg uprawomocnionych przez autorytet ministerstwa określonych zachowań szkoły - pola działania nauczycieli i uczniów.

18 Zob. M. Pieniążek, Uczeń jako aktor kulturowy. Polonistyka szkolna w warunkach ptynnej nowoczesności, Kraków 2013; tenże, Polonistyka performatywna. O humanistycznych technologiach wytwarzania światów, Kraków 2018.

19 Tenże, Polonistyka performatywna..., dz. cyt., s. 58-59.

20 Słowa Jarosława Kaczyńskiego, cyt. za: T. Szkudlarek, Polityka wstydu i bezwstydna polityka, „Forum Oświatowe” 2018, nr 1, s. 38. Szkudlarek zauważa: „Być może zatem podstawowe wyjaśnienie łatwości, z jaką uprawiamy dziś politykę obsceniczną, bezwstydnie odwołującą się do siły większości, ignorującą prawa mniejszości i prawa jednostek do decydowania o sobie, cynicznie ignorującą także podstawowe reguły moralne nakazujące pomoc ofiarom wojen i głodu, obrażającą zasady chrześcijańskiej etyki, a za to skwapliwie korzystającą z ochrony instytucji Kościoła” (tamże, s. 48). 
Godność i duma, o której mówi polityk, zostaje wytwarzana przez zgrabną narrację historyczną tworzącą retrotopię, gwarantującą spójność wspólnoty państwowej, chroniącą przed niepokojom ponowoczesnego świata i nieznanej przyszłości ${ }^{21}$. Polityk projektuje szkołę, która będzie używała historii do jasno sprecyzowanych celów - jej wytworem ma być bowiem dumny i honorowy obywatel Polski. W tak rozumianej polityce historycznej waloryzuje się zatem nie krytyczny namysł nad przeszłością, ile narrację o naszych bohaterach, mających służyć za identyfikacyjne wzorce. W ten sposób budowana wspólnota kultywuje wsobne narracje, „bezwstydnie” zagnieżdża się w wypracowanych przez siebie opowieściach przeszłości i wypiera to, co nie mieści się w jej ramach. Dlatego też na liście lektur pojawiają się nazwiska Wojciecha Wencla, Jarosława Marka Rymkiewicza czy takie utwory, jak Syzyfowe prace Stefana Żeromskiego, Pan Tadeusz Adama Mickiewicza, omawiany już w szkole podstawowej. Podstawa programowa projektuje wizję naszej tożsamości zakleszczonej w reprodukcji romantyczno-tyrtejskiego imaginarium. Taka wizja polityki szkoły, wytwarzająca „silną” narodową tożsamość, wytwarza także jednoznaczną formułę męskości osadzoną w tradycji sarmackiej, której przejawem jest „kult męstwa (...). Idealny (...) mężczyzna sarmacki to rycerz, bohater i obrońca katolickiej wiary, uczestnik "pobożnej « wojny"22. I trzeba jeszcze dodać - heteroseksualny, stojący na straży nie tylko świątyni pamięci narodowej, ale i stający w obronie „naszych” rodzin (czy tego chcemy, czy nie) przed „inwazją" imigrantów i „promocją” nieheteronormatywnych zachowań.

Maria Janion widzi ogromne niebezpieczeństwo tak konstruowanej wizji społecznej. Badaczka z niepokojem zaznacza:

Jedną z rzeczy, które mnie wyjątkowo już denerwują, jest figura małego powstańca. To jest coś przerażającego. Dziecko przebrane za żołnierza z karabinem. Życie ludzkie, nie w postaci parę razy podzielonej komórki, ale w postaci prawdziwego dziecka, niespełna dziesięcioletniego, przestaje być najwyższą wartością, kiedy indoktrynujemy takie dziecko, że nie ma na świecie nic wspanialszego niż udanie się na śmierć w powstaniu czy w ogóle gdziekolwiek na wojnie. Muzeum Powstania Warszawskiego takie rzeczy wyrabia z dziećmi, że śmierć całkowicie się dla nich odrealnia, staje się rodzajem wielkiej przygody ${ }^{23}$.

Mitologizacja wojny, o której pisze Janion, jest zawłaszczającym gestem władzy chcącej wzmacniać poczucie przynależności i jedności, pozbawione krytycznego namysłu nad naszą przeszłością. Andrzej Leder zauważa, że projekt

${ }^{21}$ Por. Z. Bauman, Retrotopia. Jak rządzi nami przesztość?, tłum. K. Lebek, Warszawa 2018, s. 7-25.

22 T. Tomasik, Wojna - męskość - literatura, Słupsk 2013, s. 85.

23 M. Janion, Transe - traumy - transgresje. Rozmawia Kazimiera Szczuka, Warszawa 2014, s. 44-45. 
tożsamościowy oparty na dumie i wymazujący wstyd jest charakterystyczny dla słabych państwowości, niepotrafiących uczciwie zmierzyć się z własną historią. Silne państwowości - zaznacza filozof - są zdolne do przyznania się do własnych przewinień, pozwalającego na bycie „dumnym z tego, że jest się zdolnym do wstydu" ${ }^{24}$. Tym samym konserwacja sensów w tradycji, uporczywe trzymanie się retoryki dumy i honoru jest gestem obronnym, mającym ochronić przed złowrogą rzeczywistością, co - jak szczególnie podkreśla Leder - pozbawia nas nadziei wychylonej w przyszłość.

Spotkanie z literaturą jako instytucją, jeśli traktujemy je odpowiedzialnie (z ducha Derridy i Emmanuela Lévinasa, ale też Anny Janus-Sitarz i Koziołek), nie może się wpisać w jasno wyłożony pogram służący do wypracowania określonych postaw w rytm partyjnych ideologii. Zakłada bowiem pracę upodmiotowienia, której efekt może okazać się niespodziewany i nieprzewidywalny. Tworzy wspólnotę niemieszczącą się w dobrze rozpoznanych granicach tego-samego, ustanawia się w geście negocjowania sensów, a nie w ideologicznej obronie rzekomo wiecznych wartości. Myśląc o demokracji europejskiej, Derrida wskazuje, że jej wyznacznikami powinny być ciagły namysł nad własną tożsamością i jednocześnie konieczność otwarcia na to, „co nie jest, nigdy nie było i nie będzie Europą”25, co w języku francuskiego filozofa oznacza gotowość do ciągłego podważania totalitaryzmów, respektowania inności. Demokracja, która „nadchodzi”, sytuuje się antagonistycznie wobec uprawomocnionych form polityczności, chcących sprowadzić naszą egzystencję do jasno wyznaczonych ról społecznych. Jest projektem zdolnym do przemyśliwania swoich złożeń i gotowym do podjęcia odpowiedzialności wobec innego.

Przeszłość i pamięć należą do jednego z zadań edukacji polonistycznej tworzenia komunikacji społecznej, dialogu międzypokoleniowego. Z tym, że ta formuła przywracania pamięci wiąże się także z przywoływaniem faktów, które nie zawsze wpisują się w konsolidacyjną narrację narodową. A jeśli myślimy o pamięci jako formie komunikacji społecznej, to nie możemy zapomnieć o cierpieniu innych, bo właściwie pozbawia nas podstawowego namysłu nad tym, czyje życie tak naprawdę jest godne opłakiwania ${ }^{26}$. Oczywiście można by powiedzieć, że i tak szkołę „stwarzają” poszczególni nauczyciele i poszczególni uczniowie. Jednak funkcjonujemy w ramach instytucji, wytwarzających określone ramy komunikacji i chcących wyprodukować tożsamości podporządkowane ideologicznym uzurpacjom.

24 A. Leder, Rysa na tafli. Teoria w polu psychoanalitycznym, Warszawa 2016, s. 339.

25 Tamże, s. 84.

26 Zapożyczam się tutaj u Judith Butler. Zob. taż, Ramy wojny. Kiedy życie godne jest optakiwania?, tłum. A. Czarnacka, Warszawa 2011. 


\section{Wolałbym tak}

W wielokrotnie komentowanym utworze Hermana Melville'a Kopista Bartleby. Historia z Wall Street tyłowy bohater, beznamiętnie wykonujący biurową robotę polegającą na kopiowaniu dokumentów, w pewnym momencie odmawia swemu przełożonemu wykonania polecenia. Narrator-adwokat, zaskoczony osobliwym zachowaniem swego pracownika, nie kryjąc swego zdziwienia, zwraca się do czytelnika:

wezwałem Bartleby'ego, spiesząc mu oznajmić, do czego go potrzebuję - że mianowicie pragnę, by razem ze mną sprawdził poprawność niewielkiego dokumentu. Wyobraź sobie, czytelniku, jak bardzo byłem skonsternowany, gdy, nie ruszywszy się ze swojego odosobnienia, Bartleby odpowiedział mi uprzejmie acz stanowczo: Wolałbym nie ${ }^{27}$.

Tak rozpoczyna się seria kolejnych odpowiedzi Bartleby’ego „I would prefer not to" - co w języku polskim oddano jako „wolałbym nie”. Polskie tłumaczenie zaciemnia jednak znaczenie czasownika to prefer, oznaczającego „preferować”, „przedkładać” ${ }^{28}$. Konstatacja (naruszająca zasady angielskiej gramatyki) „I would prefer not to”, pojawiająca się w różnych sytuacjach, wyzwala - jak by powiedział Agamben - język potencjalności: „stan zawieszenia między twierdzeniem a przeczeniem, akceptacją a odmową, uznaniem a odrzuceniem" 29 . Osobliwa formuła, którą posługuje się kopista, wyrywa adwokata, niemogącego pojąć zachowania swojego pracownika, z dobrze skonstruowanego biurokratycznego świata. Można w niej usłyszeć gest sprzeciwu wobec języka zarządzająco-administracyjnego, wyznaczającego określone pozycje społeczne wsparte na

${ }^{27}$ H. Melville, Kopista Bartleby. Historia z Wall Street, tłum. A. Szostkiewicz, Warszawa 2009, s. 19. Gilles Deleuze skrupulatne wymienia jeszcze dziewięć przypadków, prócz tego, który przywołałem wyżej: „Drugi, gdy adwokat prosi Bartleby’ego, by przyszedł do niego sczytać własne kopie. Trzeci, gdy adwokat nakłania Bartleby’ego do sczytania kopii z nim osobiście, twarzą w twarz. Czwarty, gdy adwokat chce go wysłać na posyłki. Piąty, gdy każe mu przejść do sąsiedniego pokoju. Szósty, gdy pewnego niedzielnego poranka adwokat chce wejść do swojego biura i widzi, że Bartleby w nim śpi. Siódmy, gdy adwokat poprzestaje na zadawaniu pytań. Ósmy, gdy Bartleby przestaje kopiować, rezygnuje z wszelkiego kopiowania, a adwokat go wyrzuca. Dziewiąty, gdy adwokat podejmuje drugą próbę wyrzucenia go. Dziesiąty, gdy Bartleby zostaje usunięty z biura, siada na poręczy schodów, a wystraszony adwokat proponuje mu inne nieoczekiwane zajęcia” (G. Deleuze, Bartleby, czyli formuta [w:] tegoż, Krytyka i klinika, tłum. B. Banasiak, P. Pieniążek, Łódź 2016, s. 116).

${ }_{28}$ Zob. uwagi tłumacza tekstu Agambena S. Królaka [w:] H. Melville, Kopista Bartleby..., dz. cyt., s. 127.

${ }_{29}$ G. Agamben, Bartleby, czyli o przypadkowości, tłum. S. Królak [w:] H. Melville, Kopista Bartleby..., dz. cyt., s. 129. 
zasadzie hierarchicznej zależności ${ }^{30}$. Mimo że nasz bohater umiera, jego sprzeciw i śmierć prowadzą do wybicia maszyny administracyjnej z przypisanego jej rytmu. Dla Oskara Szwabowskiego nauka płynąca z opowiadania jest jasna:

Mówiąc krótko, krytyka ma charakter praktyczny, związany z budowaniem odmiennych relacji społecznych, związany z mocą bytu przeciwko sile dominujących struktur. Nie podziela iluzji, że w instytucjach funkcjonujących i wspierających dominujący dyskurs jest się w stanie wynegocjować inne sposoby życia i użycia. Opuszcza fabryki (edukacyjne), by tworzyć nomadyczne maszyny edukacyjne, pirackie sieci - umierać dla tego świata i rodzić się dla innego. Robiąc prześwity, które mogą uwodzić również w tym, co dominuje $\mathrm{e}^{31}$.

Formuła Bartleby’ego „wołałbym nie” dobrze ukazuje uwikłanie pracy nauczyciela w instytucję szkolną, skazaną na biurokratyczną i administracyjną przemoc rozumu instrumentalnego. Szkoła, z którą mamy do czynienia, jest maszynerią podporządkowaną jasno zaprojektowanym celom edukacji, poddaną egzaminom zewnętrznym - czy to po ukończeniu szkoły podstawowej czy średniej, co prowadzi nie tylko do biurokratycznego wypełnienia poszczególnych treści nauczania, ale i sprowadzenia edukacji polonistycznej do kształcenia wymiernych umiejętności, łatwych do sprawdzenia i pomiaru. Ministerstwo myśli o szkole w kategoriach pasa transmisyjnego, w którym to nauczyciel przekazuje wiedzę uczniowi. Nie widzi w edukacji przestrzeni doświadczenia/ eksperymentu, w której uczniowie próbują sami konstruować wiedzę, a nie do niej docierać. Mamy więc do czynienia ze szkołą pojętą jako system, do którego musi się uczeń dostosować, niezależnie od intelektualnego i emocjonalnego rozwoju, a jej zwieńczeniem okazuje się egzamin maturalny mający na celu drobiazgowe sprawdzenie opanowania katalogu treści podstawy programowej i znajomości lektur obowiązkowych. Zofia Anna Kłakówna słusznie zauważa:

Egzaminy powinny odpowiadać modelowi edukacji opisanemu w podstawie programowej. Modelowi - nie detalicznym wyliczeniom zagadnień. Egzaminów dotyczy też przekonanie, że nie można pytać o coś, czego szkoła nie miała w obowiązku uczyć, czyli że materiał, jak na przykład lista lektur, siłą rzeczy musi być dla wszystkich odgórnie wyznaczony i obowiązkowy. Wystarczy jednak pomyśleć, że sprawdzać trzeba raczej umiejętności, by nagle się okazało, że odmienność poznawanego materiału nie ma decydującego znaczenia, że ważniejsze jest tworzenie warunków głębokiego przetwarzania podejmowanych treści oraz że decydująca jest

30 Por. O. Szwabowski, Bartleby, towca dyskursów. O pewnej formie nie-krytyki, „KulturaSpołeczeństwo - Edukacja” 2017, nr 2 (12), s. 329-344.

31 Tamże, s. 343. 
waga podejmowanej problematyki. To ważne problemy „wywołują do odpowiedzi" naprawdę ważne teksty ${ }^{32}$.

Jednowymiarowa edukacja umacnia dominację rozumu instrumentalnego, obsesję parametryzacji, obliczonej na wywoływanie określonych efektów, podporządkowana kategoriom skuteczności i produktywności ujawnia się w biurokratycznym posłuszeństwie - głupocie oraz pogoni za coraz to nowszymi metodami, mającymi „zwiększyć” efektywność kształcenia, które można przeciwstawić skupieniu i myśleniu.

Nauczyciel, który potrafi w czasie swojej lekcji przekroczyć podporządkowany maturze proces nauczania, staje się podobny do Bartleby' ego. W ten sposób maszyna edukacyjna zaczyna zgrzytać, a przewidziane scenariusze zostają przedziurawione - szkoła staje się wydarzeniem, w którym lekcja lektury wykracza poza mury instytucji i ujawnia swoją energetyzującą siłę. W tym sensie praca nauczyciela nie zatrzymuje się na oporze, ale próbuje dać odpór instytucjonalnym uwarunkowaniom, który można by wyrazić przez kończącą Ulissesa Jamesa Joyce’a frazę: „Tak, chcę tak” („Yes will Yes”). Derrida komentuje: „Afirmacja a priori wymaga potwierdzenia, powtórzenia, zachowania i zapamiętania "tak" (...). »Tak" nigdy nie nadchodzi samo i nigdy sami nie mówimy »tak"”33. Lektura w szkole jest zatem czasem wspólnym. Nie może ona istnieć samotnie, gdyż jest w niej zawarte gościnne zaproszenie. W końcu czym mogą być i szkoła, i lekcja lektury pojmowane - wbrew szkole skupionej na wytwarzaniu „mocnych” tożsamości oraz na wynikach i efektach - jako czas wolny, jeśli nie powiedzeniem kruchemu życiu „tak”?

\section{Bibliografia}

Agamben G., Bartleby, czyli o przypadkowości, tłum. S. Królak [w:] H. Melville, Kopista Bartleby. Historia z Wall Street, tłum. A. Szostkiewicz, Warszawa 2009. Agamben G., Czym jest urządzenie?, tłum. J. Majmurek [w:] Agamben. Przewodnik Krytyki Politycznej, Warszawa 2010.

Arendt H., Kryzys edukacji [w:] tejże, Między czasem minionym a przysztym. Osiem ćwiczeń z myśli politycznej, tłum. M. Godyń, W. Madej, Warszawa 1994.

Bauman Z., Retrotopia. Jak rzadzi nami przeszłość?, tłum. K. Lebek, Warszawa 2018.

Butler J., Ramy wojny. Kiedy życie godne jest optakiwania?, tłum. A. Czarnacka, Warszawa 2011.

Deleuze G., Bartleby, czyli formuta [w:] tegoż, Krytyka i klinika, tłum. B. Banasiak, P. Pieniążek, Łódź 2016.

32 Z.A. Kłakówna, Szkota na rozdrożach, „Tematy i Konteksty” 2017, nr 12, s. 80.

33 J. Derrida, Ulysses Gramophone: deux mots pour Joyce, Paris 1987, s. 110, cyt. za: M.P. Markowski, Efekt inskrypcji. Jacques Derrida i literatura, Bydgoszcz 1997, s. 325. 
Derrida J., Inny kurs, tłum. T. Załuski, Warszawa 2017.

Derrida J., Ta dziwna instytucja zwana literatura. Z Jacquesem Derrida rozmawia Derek Attridge, tłum. M.P. Markowski, „Literatura na Świecie” 1998, nr 11-12.

Hodgson N., Vlieghe J., Zamojski P., Manifesto for a Post-Critical Pedagogy, https:// punctumbooks.com/titles/manifesto-for-apost-critical-pedagogy, dostęp: 2.10. 2019.

Janion M., Transe - traumy - transgresje. Rozmawia Kazimiera Szczuka, Warszawa 2014.

Janus-Sitarz A., W poszukiwaniu czytelnika. Diagnozy, inspiracje, rekomendacje, Kraków 2016.

Kłakówna Z.A., Szkota na rozdrożach, „Tematy i Konteksty” 2017, nr 12.

Kozak W., Komentarz do podstawy programowej przedmiotu jezyk polski na II etapie edukacyjnym [w:] Podstawa programowa ksztatcenia ogólnego z komentarzem. Szkota podstawowa. Jezyk polski, Warszawa 2017.

Koziołek K., Czas lektury, Katowice 2017.

Leder A., Rysa na tafli. Teoria w polu psychoanalitycznym, Warszawa 2016.

Markowski M.P., Efekt inskrypcji. Jacques Derrida i literatura, Bydgoszcz 1997.

Masschelein J., Simson M., In Defence of the School. A Public Issue, thum. J. McMartin, Leuven 2013.

Melville H., Kopista Bartleby. Historia z Wall Street, tłum. A. Szostkiewicz, Warszawa 2009.

Pieniążek M., Polonistyka performatywna. O humanistycznych technologiach wytwarzania światów, Kraków 2018.

Pieniążek M., Uczeń jako aktor kulturowy. Polonistyka szkolna w warunkach ptynnej nowoczesności, Kraków 2013.

Postman N., Technopol. Triumf techniki nad kulturą, tłum. A. Tanalska-Dulęba, Warszawa 2004.

Potulicka E., Rutkowiak J., Neoliberalne uwiktania edukacji, Kraków 2010.

Stiegler B., Wstrzasy. Gtupota i wiedza w XXI wieku, tłum. M. Krzykawski, Warszawa 2017.

Szkudlarek T., Polityka wstydu i bezwstydna polityka, „Forum Oświatowe” 2018, nr 1.

Szwabowski O., Bartleby, towca dyskursów. O pewnej formie nie-krytyki, „Kultura Społeczeństwo - Edukacja” 2017, nr 2 (12).

Tomasik T., Wojna-meskość- literatura, Słupsk 2013.

Vlieghe J., Zamojski P., Towards an Ontology of Teaching Thing-centred Pedagogy, Affirmation and Love for the World, Cham 2019. 